p-ISSN. 2086-9029

e-ISSN. 2654-5675

Vol. 22 No. 1, Hlm. 1-158, Juni 2020

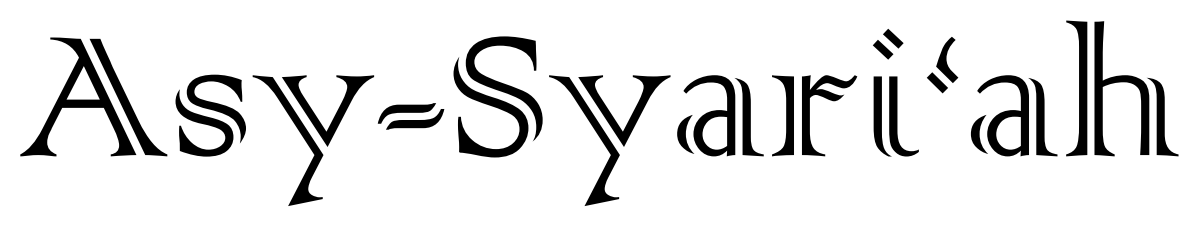

- Hukum Waris Islam Sebagai Instrumen Kepemilikan Harta

$(1-20)$ Hafidz Taqiyyudin

- Komparasi Metodologi Hukum Aliran Maqasidi dan Aliran Syakli

$(21-34)$ Hudzaifah Achmad Qotadah

- Reinterpretasi Hak Ijbar dalam Hukum Perkawinan Islam di Keluarga $(35-50)$ Pesantren

Kudrat Abdillah, Ah. Kusairi

- Dimensi Kondisionalitas dan Fleksibilitas Al-Quran bagi Implementasi Fatwa DSN-MUI tentang Produk Bank Syariah

Ahmad Hasan Ridwan, Asep Rahmat

- Validitas Hadis Tidak Ada Kisas bagi Orang Tua yang Membunuh Anaknya

Moh. Ahsanuddin Jauhari, Enceng Arif Faizal, Syahrul Anwar, Atep Mastur, Deden Najmudin

- Penguatan Resolusi Konflik Berbasis Tradisi Sunnah Nabi

Alamsyah

- Sistem Perencanaan, Pelaksanaan dan Pengawasan Industri Halal di Wilayah Provinsi Banten

Akhyakudin, Suja'i, Muhammad Abduh

- Reformulation of Family Legal in Indonesia for Female Maslahah

Wahidullah, Murniati, Yushinta Eka Farida, Jumaiyah

- The Concept and Aplication of Covenant in Financing Gold Pawn By Sharia Bank in West Java

Neni Nuraeni, Dewi Sulastri, Zulbaidah

- Tinjauan Sosiologi Hukum tentang Kepatuhan Masyarakat terhadap ( $147-158)$ Undang-Undang Wakaf

Deden Effendi

FACULTY OF SHARIA AND LAW

STATE ISLAMIC UNIVERSITY SUNAN GUNUNG DJATI BANDUNG-INDONESIA IN COLLABORATION WITH ASOSIASI SARJANA SYARIAH INDONESIA 


\section{Asy-Syari'ah}

Volume 22, Number 1, 2020

\section{EDITOR-IN-CHIEF}

Ine Fauzia

\section{EDITORIAL BOARD}

Sofyan al-Hakim, UIN Sunan Gunung Djati Bandung, Indonesia Deni Kamaludin Yusup, UIN Sunan Gunung Djati Bandung, Indonesia Meria Utama, Fakultas Hukum Univrsitas Sriwijaya, Indonesia Dewi Mayaningsih, UIN Sunan Gunung Djati Bandung, Indonesia Andrey Sujatmiko, Fakultas Hukum Universitas Trisakti, Jakarta, Indonesia Hetty Hassanah, Universitas Komputer Indonesia, Indonesia

\section{PEER-REVIEWERS}

Muhammad Irfan Helmy, IAIN Salatiga, Semarang, Indonesia Ahmad Ali Nurdin, UIN Sunan Gunung Djati Bandung Tajul Arifin, UIN Sunan Gunun Djati Bandung, Indonesia Mohamad Anton Athoillah, UIN Sunan Gunung Djati Bandung, Indonesia Mrs. Renny Supriyatni, Universitas Padjadjaran, Indonesia Ahmad Tholabi Karlie, UIN Syarif Hidayatullah Jakarta, Indonesia Ija Suntana, UIN Sunan Gunung Djati Bandung, Indonesia Zezen Zaenal Mutaqin, University of California, Los Angeles, United States Ahmad Fathonih, UIN Sunan Gunung Djati Bandung, Indonesia Rahman Syamsuddin, Universitas Islam Negeri Alauddin Makassar, Indonesia

\section{PROOFREADER/DESIGN COVER}

Nanang Sungkawa

\section{LAYOUT EDITOR}

Opik Rozikin

Asy-Syari' ah has been accredited based on the determination of Director General of Research and Development Strengthening, Ministry of Research, Technology and Higher Education of Republic of Indonesia, No. 14/E/KPT/2019 (valid until 2023). 


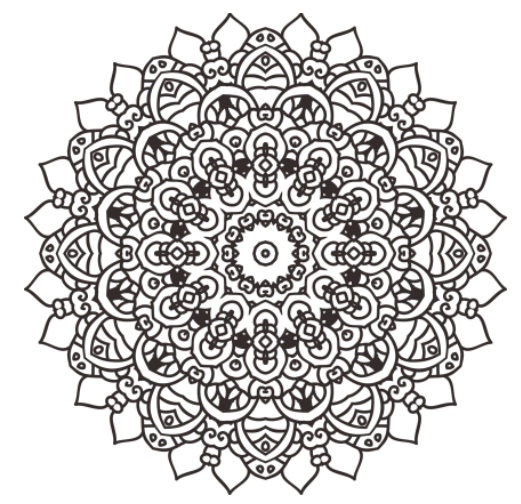

\title{
REINTERPRETASI HAK IJBAR DALAM HUKUM PERKAWINAN ISLAM DI KELUARGA PESANTREN
}

\author{
${ }^{1}$ Kudrat Abdillah, ${ }^{2}$ Ah. Kusairi \\ ${ }^{12}$ Institut Agama Islam Negeri Madura \\ E-mail: kudrat.abdillah@iainmadura.ac.id, ahkusairi18@gmail.com
}

\begin{abstract}
Marriage is an inner and outer bond between the bride and groom to weave a happy and eternal family. Marriage has a goal to reach a happy, sakinah, mawaddah, and rahmah. The selection of a bride and groom is very important to achieve the goal of marriage. Because in fact, the chosen candidate is a person who will keep him a full day of his life. The ijbar right of a guardian who can force a daughter to marry a chosen prospective husband, is considered not in line with the purpose of marriage itself. Using a social history approach, this paper will describe the concept of ijbar rights in islamic boarding school families in Pamekasan. Descriptions of ijbar rights will be discussed in several sections, continuity and changes, causal explanation, and the implications of change.
\end{abstract}

Keywords: Reinterpretation, ljbar Rights, Islamic Boarding Schools 
Abstrak: Perkawinan adalah ikatan lahir batin di antara calon mempelai untuk merajut keluarga yang bahagia dan kekal. Perkawinan mempunyai tujuan untuk mencapai keluarga yang bahagia, sakinah, mawaddah, dan rahmah. Pemilihan calon mempelai merupakan hal yang sangat penting untuk mencapai tujuan perkawinan. Karena sejatinya, calon yang dipilih adalah orang yang akan membersamainya sehari penuh seumur hidupnya. Adanya hak ijbar seorang wali yang bisa memaksakan anak perempuan untuk kawin dengan calon suami yang dipilihkan, dianggap tidak sejalan dengan tujuan perkawinan itu sendiri. Dengan menggunakan pendekatan sejarah sosial, tulisan ini akan mendeskripsikan konsep hak ijbar pada keluarga pesantren di Pamekasan. Deskripsi hak ijbar akan dibahas dalam beberapa bagian, yaitu perkembangan dan perubahan, faktor-faktor yang mempengaruhi, dan implikasinya perubahan.

Kata-kata kunci: Reinterpretasi, Hak ljbar, Pesantren 


\section{Pendahuluan}

Perkawinan mempunyai tujuan untuk membentuk keluarga yang kekal dan bahagia. Dalam khazanah Islam dikenal dengan keluarga yang sakinah, mawaddah, wa rahmah sebagai tujuan dan maksud adanya perkawinan. Untuk membentuk keluarga yang bahagia tersebut, sudah hal yang pasti ada faktor-faktor yang mempengaruhi, termasuk pemilihan calon pasangan (calon suami) yang tepat. Pemilihan calon pasangan merupakan satu hal terpenting dalam perkawinan, karena pasangan inilah yang akan menemani sepanjang hidup perkawinan tersebut.

Dalam kajian hukum Islam ada hak ijbar seorang wali (wali mujbir), untuk memaksa anak perempuannya dikawinkan dengan calon yang dipilihkan. Hak ijbar ini seakan menjadi penentu dimulainya kehidupan rumah tangga seorang perempuan. Baik suka maupun tidak suka, seorang perempuan harus menuruti keinginan ayahnya (walinya) yang memilihkan calon suami baginya. Jika menolak, maka perempuan ini dianggap sebagai anak yang tidak taat kepada orang tua, bahkan banyak yang menyebutnya anak durhaka. Hal ini menjadikan ketidakadilan bagi perempuan yang serba salah untuk melangkah. Di satu sisi ingin membentuk keluarga yang bahagia, namun di sisi lain ternyata harus dipaksa untuk menerima calon yang dipilihkan.

Bermula dari permasalahan tersebut, kajian hak ijbar akan dilihat dengan menggunakan pendekatan sejarah sosial. Sejarah sosial tercatat sebagai bagian dari perkembangan kajian sejarah yang muncul paling akhir. ${ }^{1}$ Sejarah Sosial merupakan sejarah yang meminjam ilmu-ilmu sosial guna menganalisis terkait struktur dan proses interaksi aktor sejarah sebagaimana telah terjadi dalam konteks sosio-kultural di masa dahulu.

Kajian akademik dengan menggunakan sejarah sosial, mengungkap tiga aspek berikut, perkembangan dan perubahan (continuity and change), faktor-faktor penyebab (causal explanation), dan implikasi (implication). Continuity and Change mendeskripsikan perkembangan dan perubahan satu kejadian yang ada pada masyarakat. Causal Explanation menggambarkan dengan gamblang faktor-faktor dan penyebab perubahan fenomena bisa terjadi di masyarakat. Sementara implication akan menjelaskan tentang implikasi yang akan terjadi dari proses perkembangan dan perubahan sebelumnya.

\section{Hasil dan Pembahasan}

\section{Tujuan Utama Perkawinan}

Prof. Khoiruddin menyebutkan minimal ada lima tujuan dari adanya perkawinan. ${ }^{2}$ Tujuan yang pertama untuk mendapatkan kehidupan keluarga yang sakinah, mawaddah, dan rahmah. Kedua, untuk proses reproduksi dan regenerasi keturunan keluarga besar. Ketiga, untuk memenuhi kebutuhan biologis (seksual) di antara suami

\footnotetext{
${ }^{1}$ Akh. Minhaji, Sejarah Sosial dalam Studi Islam, (Yogyakarta: Sunan Kalijaga Press, 2013), hlm. 48.

${ }^{2}$ Nasution, Khoiruddin, Hukum Perkawinan 1, (Yogyakarta: ACAdeMIA + TAZZAFA, 2005), hlm. 38.
} 
dan istri. Keempat, untuk menjaga kehormatan. Kelima, sebagai bentuk dan bagian dari ibadah.

Dalam nash al-Qur'an Surat ar-Rum ayat 21.

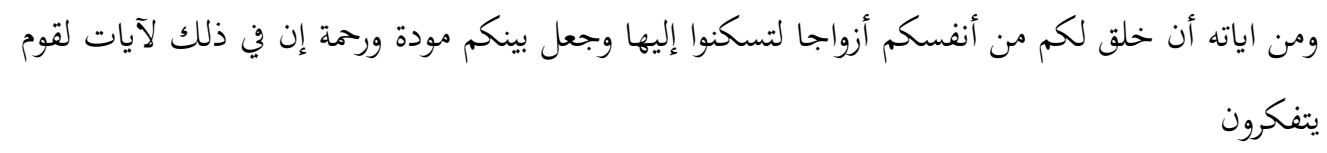

"Dan di antara tanda-tanda kekuasaan-Nya ialah Dia menciptakan untukmu istriistri dari jenismu sendiri, supaya kamu cenderung dan merasa tenteram kepadanya, dan dijadikan-Nya di antaramu rasa kasih dan sayang. Sesungguhnya pada yang demikian itu benar-benar terdapat tanda-tanda bagi kaum yang berfikir."

Qurasih Shihab menjelaskan, dalam lafadz I سكنو yang diambil dari kata سكن memiliki arti diam atau tenang setelah sebelumnya goncang dan sibuk. Juga terdapat lafadz mawaddah yang berarti cinta dan rahmat yang berarti kasih sayang. ${ }^{3}$ Sebuah rumah dinamakan dengan سكن sebab merupakan satu tempat untuk mendapatkan ketenangan setelah sebelumnya penghuni sibuk keluar rumah. Perkawinan dapat melahirkan ketenangan batin, setiap manusia dilengkapi oleh Allah dengan jenis kelamin, yang tidak dapat berfungsi secara sempurna jika ia berdiri sendiri.

Sementara itu, literatur lain tentang ayat tersebut seperti Hamka, memahami adalah rasa cinta (cinta/kerinduan seorang suami kepada seorang istri dan sebaliknya seorang istri kepada seorang suami yang dijadikan Allah sebagai hal yang wajar). Setiap lakilaki dan perempuan yang normal akan selalu mencari teman hidup bersama, sebagai tempat untuk meluapkan kasih dan sayang, serta melampiaskan persetubuhan. Dengan persetubuhan/hubungan sesual dapat memperkuat hubungan kasih sayang di antara mereka. ${ }^{4}$

Muhammad Al Maraghi berpendapat bahwa Allah menciptakan pada diri mereka nafsu atau naluri seksual. Karena itu, setiap jenis (manusia) tersebut merasa perlu menemukan lawan jenisnya, dan ini dari hari ke hari memuncak dan mendesak dalam hal pemenuhannya. Akibatnya akan merasa gelisah, pikirannya kacau dan jiwanya akan terus bergejolak apabila persetubuhan dan pelampiasan nafsu dengan pasangan tidak terpenuhi. Karena itulah, Allah mensyariatkan perkawinan bagi manusia sebagai penyembuh atas kekacauan pikiran dan gejolak jiwa supaya masing-masingnya memperoleh ketenangan. Setelah manusia dapat menemukan jodohnya dan mendapatkan keturunan sebagaimana yang diharapkan maka dalam keluarga tersebut akan tercipta suatu kondisi yang penuh dengan ketenangan, ketentraman, dan kedamaian sebagaimana dimaksud dengan kata mawaddah warahmah. ${ }^{5}$

\footnotetext{
${ }^{3}$ Quraish Shihab, Muhammad, Tafsir Al-Misbâh, Jilid II, (Bandung: Lintera Hati, 2004), hlm. 35.

${ }^{4}$ Hamka, Tafsîr al-Azhâr, Juz 21, 22, 23 dan 24, (Jakarta: Yayasan Nurul Islam, 1984), hlm. 84.

${ }^{5}$ Al-Maraghi, Tafsîr Al-Marâghi, Jilid 17, Alih Bahasa Bahrun Abu Bakar, Cet Kedua, (Semarang: Toha Putra, 1993), hlm. 45 .
} 
Dalam Tafsir Jalalain, ada pemisahan antara makna yang terkandung dalam مودة , سكنة dan سكنة yang dimaknai sebagai ketenangan dan ketentraman dalam

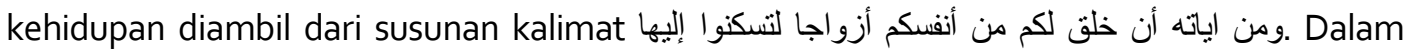
kalimat tersebut terdapat kata kerja pembentuk, yaitu خلق خلق خور lebih rinci diartikan sebagai "menciptakan". Artinya, ketenangan dan ketentraman hidup hanya dapat diperoleh dengan kehendak Allah semata. Sementara lafadz مودة dan رحمة yang dimaknai sebagai kasih sayang dan rahmat diambil dari susunan kalimat وجعل بينكم مودة ورحمة ردة لودة. Pada kalimat tersebut, terdapat kata kerja pembentuk yaitu جعل., lafadz ini menunjukkan arti "menjadikan".

Dalam ayat tersebut, untuk mencapai kehidupan yang sakinah, harus ditopang dan didukung dengan kehidupan yang mawaddah dan kehidupan yang rahmah. Kehidupan yang sakinah hanya bisa diciptakan (خلق) oleh Allah, SWT. Sedangkan pada kehidupan yang mawaddah dan rahmah, Allah, SWT tidak menciptakan, tetapi menjadikan (جعل). Artinya, kehidupan sakinah hanya menjadi hak prerogatif Allah, SWT. tanpa campur tangan manusia. Sementara kehidupan yang mawaddah dan warahmah ada unsur usaha manusia, meskipun pada akhirnya Allah yang menentukan.

Tujuan perkawinan paling utama adalah mencapai kehidupan yang sakinah, mawaddah dan rahmah. Rasa-rasanya sangat mustahil ketika perkawinan dimulai dari paksaan akan berakhir dengan kebahagiaan. Meskipun banyak kasus yang bahagia, tetapi tidak sedikit pula kasus perkawinan paksa yang berakhir pada perceraian. Padahal perceraian inilah yang melukai prinsip perkawinan sebagai perjanjian yang kekal dan abadi. Maka dari itu, pada poin pemilihan pasangan merupakan hal yang paling menentukan dalam keutuhan rumah tangga. Karena dengan memilih pasangan yang tepat, pasangan yang disenangi, akan mendukung hubungan suami istri rukun dan bahagia. Dengan begitu tujuan perkawinan bisa tercapai dengan baik.

\section{Hak ljbar dalam Hukum Islam}

Pembahasan hak ijbar dalam hukum Islam, ditampilkan dengan pendapat-pendapat ulama mazhab yang terkenal. Ulama Mazhab yang terkenal dibatasi dalam empat mazhab, yaitu Mazhab Maliki, Mazhab, Hanafi, Mazhab Syafi'I, dan Mazhab Hambali.

Pendapat Mazhab Maliki (Malik ibn Anas bin Malik bin Amr al-Asbahi/ Malik bin Anas)

Menurut Imam Malik (sebagai pendiri Mazhab Maliki), dalam membahas hak ijbar seorang wali, harus memisahkan antara calon istri yang gadis dan janda. Untuk calon istri yang janda, harus dimintai persetujuan terlebih dahulu sebelum dilaksanakan akad nikah. ${ }^{7}$ Keterangan persetujuan itu harus diketahui dengan jelas dan tegas. Sehingga tidak menimbulkan penafsiran lain.

\footnotetext{
${ }^{6}$ Jalaluddin al-Mahalli, Jalaluddin as-Suyuthi, Kitab Tafsir Jalalain.

${ }^{7}$ Sahnun, al-Mudawwanah, Jilid III, (), hlm. 162.
} 


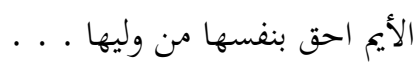

"Janda lebih berhak menentukan atas dirinya daripada walinya..."

Pada hadis tersebut, menurut pendapat 'lyad, seorang janda mempunyai hak untuk menentukan perkawinannya. Artinya seorang janda tersebut berhak menolak dikawinkan oleh walinya atau juga bisa menerimanya. Tetapi dalam hal perkawinan, seorang janda tidak bisa menikahkan dirinya sendiri, meskipun lebih berhak menentukan dengan siapa dia akan kawin. ${ }^{8}$

Bagi anak perempuan yang masih gadis, ayah bisa memaksanya untuk kawin dengan calon yang dipilihkan. ${ }^{9}$ Dengan begitu, seorang ayah memiliki hak ijbar, tanpa harus mendapatkan izin dan persetujuan dari anak perempuannya. Seperti yang tersebut dalam dasar di bawah ini:

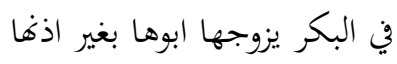

"Anak gadis dikawinkan oleh walinya meskipun tanpa izinnya"

Selain dengan dasar tersebut, kebolehan seorang ayah memaksa anak perempuannya kawin, diambil dari pemahaman terbalik (مفهوم مخالفة) dari pernyataan bahwa seorang janda lebih berhak menentukan perkawinannya. Maka dari itu, hukumnya sunah meminta persetujuan anak perempuan yang masih gadis untuk dikawinkan.

Sementara wali yang bukan ayahnya (paman, saudara laki-laki, dll) tidak mempunyai hak ijbar atau tidak berhak untuk memaksa. Apabila wali dari anak gadis sudah meninggal, maka hak perwalian jatuh kepada urutan wali lain yang masih hidup. Waliwali yang bukan ayahnya tersebut tidak memiliki hak untuk memaksakan kawin seperti haknya ayah sebagai wali, meskipun sama-sama menempati posisi wali.

\section{Pandangan Mazhab Hanafi (Nu'man bin Tsabit bin Zuta bin Mahan at-Taymi)}

Menurut Imam Abu Hanifah, dalam setiap perkawinan mengharuskan adanya persetujuan perempuan, baik yang sudah janda ataupun yang masih gadis. Persetujuan tersebut yang akan menentukan apakah perkawinan bisa dilaksanakan atau tidak. Dengan begitu, apabila mereka - gadis atau janda - menyetujuinya, perkawinan bisa dilaksanakan. Sebaliknya apabila menolak, perkawinan tidak boleh dilaksanakan meskipun itu oleh ayah kandungnya sendiri.

Landasan yang digunakan Imam Abu Hanifah, terkait hal harus adanya persetujuan anak perempuan yang masih gadis dalam perkawinan adalah peristiwa perkawinan alKhansa'a di masa Nabi Muhammad SAW. Pada peristiwa tersebut Nabi menyatakan

${ }^{8}$ Ibnu 'Abdi al-Baqi bin Yusuf al-Zarqani, Sharh Muwatta' al-Imam Malik, (Mesir: Maktabah wa Matba'ah Mustafa al-Babi al-Halabi wa Awladih, 1962), hlm. 6.

${ }^{9}$ Imam Malik, al-Muwatta', Bab Nikah, (), Hadits No. 967. 
dengan tegas menolak perkawinan seorang gadis yang dikawinkan ayahnya, karena gadis tersebut tidak menyetujui. Dalam peristiwa tersebut, al-Khansa'a telah menemui Nabi dan menyampaikan kejadian yang menimpanya, yaitu dia dikawinkan ayahnya dengan anak saudara ayahnya yang tidak disukainya. Kemudian Nabi bertanya kepada al-Khansa'a apakah sempat diminta izin persetujuan, ternyata al-Khansa'a menyatakan bahwa dirinya tidak senang dengan pilihan ayahnya. Nabi kemudian menyuruhnya pergi dan menetapkan hukum dari perkawinannya tidak sah, sambil berpesan kepada alKhansa'a untuk kawin dengan orang yang dia senangi. ${ }^{10}$

Rujukan lain yang digunakan Imam Abu Hanifah adalah:

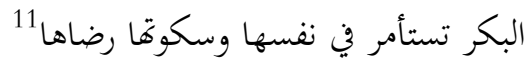

"Anak gadis (dikawinkan) atas persetujuannya, dan diamnya adalah tanda setujunya".

Hadits ini adalah kelanjutan dari hadis terkait janda yang lebih berhak menentukan perkawinannya. Hadis ini menyatakan bahwa seorang wali boleh mengawinkan anak perempuan yang masih gadis dengan syarat adanya persetujuan. Persetujuan yang dimaksud cukup dilihat dengan diamnya. Dengan diam tersebut dapat diartikan sebagai sikap rela untuk dikawinkan. Secara komprehensif dari pendapat Imam Abu Hanifah bisa ditarik kesimpulan bahwa persetujuan calon mempelai perempuan, baik yang masih gadis ataupun sudah janda, persetujuan keduanya merupakan hal yang sangat menentukan perkawinan bisa dilaksanakan.

Pandangan Mazhab Syafi'i (Abu Abdullah Muhammad bin Idris al-Syafi'i/ Muhammad bin Idris al-Syafi'i)

Berbeda dengan pandangan Imam yang lain, Imam Syafi'i dalam membahas hak ijbar seorang wali membagi menjadi tiga klasifikasi:

Pertama, Gadis belum dewasa.. Batasan yang ditetapkan oleh Imam Syafi'i untuk menentukan kedewasaan seorang gadis adalah di bawah 15 tahun atau belum mengalami haid. Untuk gadis yang belum dewasa ini, ayah boleh mengawinkan anak gadisnya dengan tanpa persetujuannya. Kebolehan tersebut dengan ketentuan bahwa perkawinannya menguntungkan dan tidak merugikan bagi anak gadisnya. ${ }^{12}$

Dasar rujukan hak ijbar yang digunakan Imam Syafi'i adalah perkawinan Nabi dengan 'Aisyah anak perempuan Abu Bakar yang masih berumur enam tahun, meskipun Nabi mulai menggaulinya ketika berumur sembilan tahun. Abu Bakar mengawinkan 'Aisyah yang masih belum dewasa - di bawah 15 tahun dan belum haid dengan alasan

\footnotetext{
${ }^{10}$ Shams al-Din al-Sarakhsi, al-Mabsut, V, (Beirut: Dar al-Ma'rufah, 1989), hlm. 10.

${ }^{11} \mathrm{Ibid}, \mathrm{hlm} .8$.

${ }^{12}$ Abu al-Walid Muhammad bin Ahmad bin Rusyd al-Qurthubi al-Andalusi, Bidâyat al-Mujtahid wa Nihâyat al-Muqtasid, Vol. II, (Beirut: Dar al-Fikr,t.t), hlm. 4-5.
} 
bahwa semua urusan anak kecil merupakan tanggung jawab ayahnya. Imam Syafi'i menjadikan kasus ini sebagai dasar penetapan hak ijbar pada anak yang belum dewasa. ${ }^{13}$

Kedua, Gadis dewasa.Anak gadis yang sudah lebih dari 15 tahun atau sudah mengalami haid, oleh Imam Syafi'i masuk kategori gadis dewasa. Bagi gadis dewasa, menurut Imam Syafi'i ada keseimbangan hak antara ayah dan anak gadisnya. Namun ada penekanan bahwa ayah lebih berhak dalam menentukan perkawinan anak gadisnya. Penetapan ini berdasar pada pemahaman terbalik (مفهوم مخالفة) atas hadis yang menyatakan seorang janda lebih berhak atas dirinya sendiri dalam menentukan perkawinan. Imam Syafi'i menyimpulkan bahwa izin anak perempuan yang masih gadis bukanlah suatu keharusan tetapi hanya sekedar pilihan. ${ }^{14}$

Ketiga, Janda. Pada klasifikasi ketiga, Imam Syafi'i mengharuskan adanya izin dan persetujuan secara tegas dari yang bersangkutan. Seorang janda memang lebih berhak terhadap dirinya sehingga untuk menyempurnakan perkawinan haruslah dengan persetujuannya. Tetapi meskipun lebih berhak menentukan perkawinannya, seorang janda tidak bisa menikahkan dirinya tanpa adanya wali.

Pandangan Mazhab Hambali (Abu Abdillah Ahmad bin Muhammad bin Hanbal)

Pendapat Ibnu Qudamah dari mazhab Hambali menyebutkan bahwa ulama telah bersepakat adanya hak ijbar bagi wali untuk mengawinkan anak perempuan yang masih gadis. Tidak ada keharusan anak gadis tersebut belum dewasa, bahkan termasuk gadis yang sudah dewasa. Hak ijbar ini tidak mempertimbangkan yang bersangkutan merasa senang atau tidak. Akan tetapi, Ibnu Qudamah memberikan ketentuan bahwa dalam perkawinan tersebut antara calon suami dengan calon istri merupakan sekufu atau seimbang.

Rujukan dasarnya adalah al-Our'an Surat at-Talaq (65) ayat 4 :

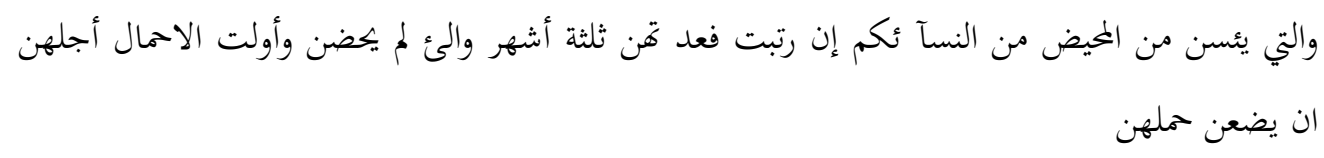

"Perempuan-perempuan yang tidak haid lagi (menopause) di antara istri-istrimu jika kamu ragu-ragu (tentang masa idahnya) maka idahnya adalah tiga bulan, dan begitu pula perempuan-perempuan yang tidak haid. Sedangkan perempuanperempuan yang hamil, waktu idah mereka itu adalah sampai mereka melahirkan kandungannya.."

Pada ayat ini, memang membahas terkait dengan masa idah seorang perempuan yang belum haid atau pun perempuan yang sudah putus haid. Dengan begitu, analogi yang digunakan sederhana adalah idah muncul karena talaq, dan talaq muncul karena kawin.

\footnotetext{
${ }^{13}$ Nasution, Khoiruddin, Hukum Perkawinan 1, (Yogyakarta: ACAdeMIA + TAZZAFA, 2005), hlm. 87.

${ }^{14}$ Ibid, hlm. 88.
} 
Secara tersirat ayat ini menunjukan bolehnya seorang perempuan yang belum haid (belum dewasa) untuk kawin. Sementara dasar hadis tentang kebolehan mengawinkan perempuan yang belum dewasa, menurut Ibnu Qudamah merujuk pada contoh Nabi Muhammad yang mengawini 'Aisyah anak Abu Bakar saat masih berumur enam tahun.

Menurut Ibn Qayyim al-Jauziyah berbeda pendapat tentang perkawinan tidak harus dengan persetujuan gadis, didasarkan pada kebalikan paham hadis "seorang janda lebih berhak pada dirinya dari pada wali". Ibn Qayyim al-Jauziyah justru berpandangan bahwa tunjukan langsung hadis ini mestinya harus lebih diutamakan daripada mengambil makna sebaliknya. Sebabnya, penetapan hukum kasus belum tentu menetapkan hukum sebaliknya, bisa jadi suatu kasus lain memiliki dasar hukumnya sendiri. Alasan paling kuat menolak pendapat kelompok tersebut adalah hadis Nabi yang mengharuskan meminta persetujuan untuk perkawinan seorang gadis.

\section{Hak ljbar dalam Hukum Positif Indonesia}

Perkawinan adalah ikatan lahir dan batin antara calon suami dan calon istri untuk merajut rumah tangga yang bahagia. Perkawinan berdasarkan perundang-undangan di Indonesia, harus dilakukan atas dasar persetujuan kedua belah pihak, calon suami dan calon istri. ${ }^{15}$ Artinya, tanpa adanya persetujuan antara calon suami dan calon istri, maka perkawinan semestinya tidak boleh dilaksanakan.

Persetujuan kedua mempelai - calon suami dan calon istri - juga tersurat dalam Kompilasi Hukum Islam (KHI). ${ }^{16}$ Perkawinan mengharuskan adanya persetujuan antara pasangan yang akan menikah memiliki arti tidak memaksa. Dengan begitu, ayah atau wali calon istri tidak bisa memaksakan perkawinan anak gadisnya. Dengan kata lain, tidak ada lagi hak ijbar untuk memaksakan anak gadisnya menikah dengan seseorang yang dipilihkan orang tuanya.

Persetujuan calon istri yang dimaksud dalam $\mathrm{KHI}$ tersebut, bisa ditunjukkan dengan pernyataan yang tegas bahwa dirinya setuju dan menerima akan perkawinannya. Selain itu juga bisa ditunjukkan dengan tulisan yang menyatakan kerelaan untuk kawin. Bahkan bisa berupa diam - diam karena malu - yang diperlihatkan, dalam arti tidak menolak adanya perkawinan. Pernyataan diam yang berarti setuju ini untuk calon-calon mempelai yang mengalami tuna rungu atau tuna wicara.

$\mathrm{KHI}$ sangat menjamin suatu perkawinan memang atas persetujuan kedua calon mempelai. Hal ini ditunjukkan dalam proses akad nikah. Sebelum akad nikah dilaksanakan, Pegawai Pencatat Nikah $\left(\mathrm{P}_{2} \mathrm{~N}\right)$ harus terlebih dahulu menanyakan persetujuan perkawinan

\footnotetext{
${ }^{15}$ Undang-Undang No. 1 Tahun 1974 tentang Perkawinan, Pasal 6 ayat (1): Perkawinan didasarkan atas persetujuan kedua calon mempelai.

${ }^{16}$ Kompilasi Hukum Islam, Inpres No. 1 Tahun 1991 Pasal 16 ayat (1): Perkawinan didasarkan atas persetujuan calon mempelai. (2) Bentuk persetujuan calon mempelai wanita, dapat berupa pernyataan tegas dan nyata dengan tulisan, lisan atau isyarat tapi dapat juga berupa diam dalam arti selama tidak ada penolakan yang tegas.
} 
kepada masing-masing calon mempelai. Apabila kemudian ditemukan pernyataan atau sikap yang menunjukkan ketidaksetujuan akan adanya perkawinan, maka perkawinan tersebut tidak dapat dilaksanakan. ${ }^{17}$

Orang tua semestinya melindungi anaknya dengan sepenuh hati. Apalagi pada perkara perkawinan yang semua orang menginginkan sekali seumur hidup. Negara sebagai tempat tinggal seluruh warganya juga berusaha melindungi, termasuk melindungi anak dari ancaman dan tekanan orang tua yang tidak baik. Negara mengatur hak-hak anak yang juga sebagai kewajiban orang tua terhadap anak. ${ }^{18}$

Banyak terjadi kasus seorang ayah enggan menikahkan anak gadisnya dengan alasan tidak senang dengan calon suami pilihan anaknya. Padahal alasan yang diutarakan ayah tidak jelas dan tidak berdasar. Mungkin juga karena sang ayah ingin membuat anaknya menderita, dengan tidak menikahkan dan tidak merestui calon menantunya. Hal ini sangat merugikan anak gadisnya.

Mengantisipasi hal-hal yang demikian itu, $\mathrm{KHI}$ juga mengatur apabila calon menantu tidak disetujui atau tidak direstui oleh wali, maka calon mempelai istri bisa mengajukan permohonan wali $a^{\prime}$ dhal. ${ }^{19}$ Permohonan ini diajukan ke Pengadilan Agama (PA) dengan alasan ayah atau walinya enggan mengawinkannya. Jika PA mengabulkan permohonan, maka hak wali akan dialihkan ke wali hakim. Sehingga proses perkawinan akan tetap bisa dilaksanakan, karena hak kewaliannya sudah berpindah ke wali hakim.

\section{Perubahan Pemaknaan Hak ljbar}

KH. Faiq Abd. Ghafur, selaku Pengasuh Pondok Pesantren Al-Mujtama' Plakpak menyatakan bahwa sebenarnya di satu sisi ada baiknya orang tua memaksakan anaknya menikah dengan pasangan pilihan ayahnya. Alasannya disamping sudah jelas menjadi pilihan yang terbaik, juga di kalangan pesantren sudah jelas nasab atau keturunannya. ${ }^{20}$ Akan tetapi untuk zaman sekarang harus ada pola yang lebih baik di bandingkan zaman dahulu. Zaman dahulu akan dengan mudah ayah atau walinya menikahkan anaknya,

${ }^{17}$ Kompilasi Hukum Islam, Inpres No. 1 Tahun 1991 Pasal 17 ayat (1) Sebelum berlangsungnya perkawinan Pegawai Pencatat Nikah menanyakan lebih dahulu persetujuan calon mempelai di hadapan dua saksi nikah. (2) Bila ternyata perkawinan tidak disetujui oleh salah seorang calon mempelai maka perkawinan itu tidak dapat dilangsungkan.

${ }^{18}$ Undang-Undang Perlindungan Anak No. 23 tahun 2002, Pasal 26 tentang kewajian dan tanggung jawab orang tua: "Orang tua berkewajiban dan bertanggung jawab untuk: a) mengasuh, memelihara, mendidik, dan melindungi anak; b) menumbuh kembangkan anak sesuai dengan kemampuan, bakat, dan minatnya; dan c) mencegah terjadinya perkawinan pada usia anak-anak". Pasal ini jelas mengamanatkan, orang tua wajib mencegah terjadinya perkawinan pada usia anak-anak, apalagi dalam konteks pernikahan yang dipaksakan.

${ }^{19}$ Kompilasi Hukum Islam, Inpres No. 1 Tahun 1991 Pasal 17 ayat (1) Wali hakim baru dapat bertindak sebagai wali nikah apabila wali nasab tidak ada atau tidak mungkin menghadirkannya atau tidak diketahui tempat tinggalnya atau gaib atau adlal atau enggan. (2) Dalam hal wali adlal atau enggan maka wali hakim baru dapat bertindak sebagai wali nikah setelah ada putusan pengadilan Agama tentang wali tersebut.

20 Wawancara Hari Ahad tanggal 11 Agustus 2019 di Pondok Pesantren Al-Mujtama' Plakpak Pamekasan. 
bahkan mungkin anaknya sama sekali tidak mengetahui - apalagi mengenal - calon suaminya. Zaman sekarang harus ada komunikasi dengan yang bersangkutan agar hasilnya maksimal. Hak ijbar tidak bisa dipaksakan dan dilaksanakan dengan begitu saja, tetapi harus ada komunikasi yang baik, sikap saling terbuka dalam keluarga, dan prinsip musyawarah.

Pola-pola baru harus dimunculkan, seperti dengan cara memberikan arahan kepada anak perempuannya agar mengikuti jejak orang tuanya yang dulu juga ketika mau menikah dipilihkan jodohnya. Pertimbangan yang diberikan dengan memperlihatkan ayahnya berhasil dan membina keluarga dengan bahagia. Maka dari itu, walinya ingin keberlangsungan perkawinan anaknya juga berhasil seperti orang tuanya. ${ }^{21}$

Perkawinan anak perempuan di keluarga pesantren dengan memilihkan calon suami sesungguhnya bukan hak ijbar penuh atau sama sekali memaksa, tetapi melakukan pertimbangan agar perkawinan anaknya berjalan dengan baik. Mungkin memang terkesannya dipaksa, akan tetapi dipaksanya kepada pilihan yang sudah jelas kebaikannya, jelas keturunannya, dan berasal dari keluarga yang terhormat. ${ }^{22}$ Menurut KH. Abd. Aziz, pemilihan calon suami dari anaknya ini memiliki tujuan yang jauh daripada hanya membentuk keluarga yang bahagia. Tujuan lainnya adalah pesan dari sesepuh yang tidak ingin ikatan kekerabatan atau ikatan keluarga terputus. Harapannya juga calon yang dipilihkan bisa menjadi pengganti dalam meneruskan perjuangan mereka mengembangkan pesantren yang sudah lama dirintis. ${ }^{23}$

$\mathrm{KH}$. Musleh Adnan, juga menyampaikan alasan pemilihan calon tersebut adalah untuk menyambung silaturahim yang semakin lama semakin jauh. Cara yang harus dilalui adalah dengan ikut andil dalam pemilihan calon suami anaknya. Dengan harapan jika terjadi perselisihan bisa diselesaikan secara kekeluargaan. Selain itu juga bisa menjaga harkat martabat dan nama baik pesantren dalam melanjutkan misi dakwah dan pendidikannya. Tetapi tidak menutup kemungkinan bahwa anak perempuan bisa mengajukan calon yang dipilihnya.

Zaman sekarang perkembangan sosial sudah semakin maju dan beragam. Anak-anak perempuan harus diberikan pemahaman agama mulai dari kecil terutama berkaitan dengan akhlak, terutama dalam berinteraksi dengan orang banyak. Berkaitan dengan memilih calon suami, keluarga pesantren sebenarnya memberikan ruang dan kesempatan kepada anak perempuan. Akan tetapi dengan memberi pertimbangan baik dan buruknya karena

\footnotetext{
${ }^{21}$ Wawancara dengan KH. Abdullah, Pada Hari Rabu tanggal 21 Agustus 2019 di Pondok Pesantren Miftahul Ulum Madukawan Pegantenan, Pamekasan.

${ }^{22}$ Wawancara dengan KH.Zainul Arifin, Pada Hari Kamis Tanggal 22 Agustus 2019 di Pondok Pesantren Ummul Quro Putra Pamekasan.

${ }^{23}$ Wawancara dengan KH. Abd. Aziz, Pada Hari Ahad Tanggal 11 Agustus 2019 di Pondok Pesantren Al-Inayah Sumber Batu Pamekasan dan KH. Basri Hasan, Pada Tanggal Kamis 22 Agustus 2019 di Pondok Pesantren Ummul Quro Putri Pamekasan.
} 
perkawinan akan dilalui sekali dalam seumur hidup dan kalau bisa di dunia sampai di akhirat. $^{24}$

Dalam catatan sejarah hak ijbar - sebagai hak wali memaksa anak perempuannya untuk menikah - mengalami perubahan. Pada masa awal pensyariatan Hukum Islam, hak ijbar mutlak dimiliki oleh wali. Terlihat dalam kajian kitab-kitab konvensional yang ditunjukkan pada empat mazhab yang terkenal seperti Imam Maliki, Imam Hanafi, Imam Syafi'i, dan Imam Hambali. Imam Malik dengan tegas mengatakan bahwa wali memiliki hak ijbar untuk memaksa anak perempuannya kawin. Begitu juga Imam Hambali, tidak berbeda pendapat dengan Imam Malik.

Sementara Imam Syafi'i membagi menjadi tiga kategori, yaitu anak gadis belum dewasa, gadis dewasa, dan janda. Bagi anak gadis yang belum dewasa, wali berhak memaksa mengawinkan anaknya. Bagi gadis yang sudah dewasa, ada sisi untuk meminta persetujuannya, tetapi bukan sesuatu yang wajib, hanya diartikan sekedar pilihan. Bagi janda maka janda tersebut lebih berhak menentukan perkawinannya dengan pilihannya.

Para Imam Mazhab yang sepakat adanya hak ijbar, menganggap bahwa dirinya sebagai orang yang paling mengerti dengan apa yang terbaik bagi anak gadisnya, jadi bisa ditarik kesimpulan kebahagiaan ini dirumuskan oleh wali. Anak perempuan yang masih gadis, dianggap tidak mampu untuk memutuskan sesuatu yang baik baginya. Dengan berpegang pada pengalaman wali, persetujuan dari anak bukan menjadi sesuatu yang perlu diprioritaskan, bahkan sangat dikesampingkan. Hal ini menjadikan jarak antara anak gadis dan orang tua, disebabkan kekuasaan penuh tersebut akhirnya memonopoli kepentingan dari perempuan.

Sedangkan Imam Hanafi menyatakan bahwa dalam perkawinan, wali wajib meminta persetujuan dari anak gadisnya. Artinya seorang wali tidak bisa memaksa anak perempuannya untuk menikah dengan yang dipilihkannya. Sehingga seorang wali tidak mempunyai otoritas yang melewati batas atas perkawinan anaknya. Hak ijbar dianggap memiliki potensi yang dapat menimbulkan berbagai macam kekerasan terhadap perempuan. Hal ini justru melenceng dari tujuan dan hakikat perkawinan.

Munculnya Undang-Undang Nomor 1 Tahun 1974 tentang Perkawinan dan Kompilasi Hukum Islam, dengan jelas tidak mengakui konsep hak ijbar. Hukum positif ingin mengakui hak-hak perempuan yang selama ini dirasa sangat diskriminasi. Seakan-akan kehidupan perempuan yang akan dijalani ditentukan pada walinya. Padahal yang akan menjalani dan mengarungi kehidupan perkawinan adalah yang bersangkutan.

Ada beberapa faktor yang dijadikan alasan perubahan pemaknaan hak ijbar. Pertama adalah faktor kedewasaan. Hal ini sesuai dengan pendapat Ibnu Taimiyyah, hak ijbar bukanlah terfokus pada objeknya -gadis atau janda-, meskipun dalam beberapa hadis

\footnotetext{
${ }^{24}$ Wawancara dengan Kyai Lutfi, pada Hari Jumat tanggal 16 Agustus 2019 di Pondok Pesantren AlLatief Pamekasan.
} 
secara eksplisit tersurat janda. Hak ijbar semestinya difokuskan pada aspek kedewasaannya. Maka dari itu, hak ijbar wali akan hilang secara otomatis jika anak yang akan dikawinkannya sudah dewasa, terlepas bahwa si anak masih gadis ataupun sudah janda.

Tingkat kedewasaan setiap orang berbeda-beda. Secara bahasa, dewasa (adult) berasal dari bahasa latin, bentuk lampau participle dari kata kerja adultus yang berarti telah tumbuh menjadi kekuatan dan ukuran yang sempurna (grown to full size and strength) atau telah dewasa (matured). ${ }^{25}$ Orang dewasa adalah individu yang telah menyelasaikan pertumbuhannya dan siap menerima kedudukan baru dalam masyarakat bersama orang dewasa lainnya. ${ }^{26}$ Kedewasaan tidak bergantung pada umur seseorang, tetapi tingkat pemikiran dan sikap yang ditunjukkan dan memposisikan diri di lingkungan sekitar.

Mungkin saja, hak ijbar ini lebih cocok pada anak yang belum dewasa. Sehingga sebagai wali, ayah merasa bertanggungjawab untuk turut serta memikirkan dan merumuskan masa depan anaknya. Alasannya jelas untuk menghindari hal-hal yang tidak diinginkan, karena anak belum dewasa. Tetapi bagi yang sudah dewasa, sudah paham baik dan buruk serta pertimbangan-pertimbangan yang digunakan lebih kompleks terkait dengan kehidupan.

Faktor kedua adalah adanya pengaruh kondisi sosial dan lingkungan pada masa hadis disampaikan terkait hak ijbar, seperti yang disampaikan Yusuf al-Qardhawi. Melihat tradisi yang berlaku di masa itu, perempuan bersifat lebih pasif dibandingkan dengan laki-laki. Sehingga menciptakan paham bahwa perempuan dianggap tak pantas untuk menentukan pasangan hidupnya. ${ }^{27}$ Oleh sebab itu, gadis dideskripsikan sebagai perempuan yang kurang memahami tujuan perkawinan. Sementara anak kecil digambarkan sebagai anak yang belum bisa menggunakan fungsi akal (qushur al-'aqli). ${ }^{28}$

Konteks dan kondisi sosial masyarakat pada masa dahulu dengan sekarang berbeda. Pada zaman sekarang konteksnya mempunyai pola bahwa antara laki-laki dengan perempuan mempunyai porsi yang seimbang. Gagasan kesetaraan gender sangat berperan dan berpengaruh besar saat ini. Perempuan-perempuan sudah tidak bersikap pasif seperti dahulu kala. Bahkan perempuan kini sudah mampu bersaing dengan laki-laki. Hal ini jelas berpengaruh adanya penolakan pemaksaan perkawinan terhadap perempuan.

Faktor ketiga adalah interaksi sosial. Hak ljbar pada dasarnya memiliki maksud dan tujuan untuk perlindungan serta tanggung jawab seorang ayah kepada anaknya. Karena disebabkan kondisi anaknya yang dianggap belum atau tidak mempunyai kemampuan atau

${ }^{25}$ Elizabeth B. Hurlock, Developmental Psychology A Life Span Approach, (New York: Mc. Graw Hil Book, 1980), hlm. 265.

${ }^{26}$ S. Wojowasito, Kamus Umum Belanda Indonesia, (Jakarta: PT. Ikhtiar Baru Van Hoves, 1990), hlm. 761.

27 Yusuf al-Qardhawi, http://anawaladunsholih.blogspot.com/2011/11/kesalahan-dalam-memahamikonsep-ijbar.html.

${ }^{28}$ Kamal al-Din Muhammad al-Siwasi, Syarh Fath al-Qadir, Vol. III, (Beirut: Dar al-Fikr,t.t), hlm. 261. 
teman untuk bertindak. ${ }^{29}$ Perkembangan pergaulan saat ini tidak bisa dibatasi. Tempattempat dan fasilitas umum sangat memudahkan untuk dipergunakan sebagai media pergaulan, sehingga interaksi antara perempuan dan laki-laki sangat tinggi intensitasnya. Hal ini menjadikan perkenalan kepada orang-orang yang belum dikenal menjadi mudah.

Bukan sesuatu yang buruk berinteraksi dengan orang-orang yang belum dikenal. Dengan maksud memperluas jaringan dan silaturahim, maka hubungan sosial ini menjadi sangat dipertimbangkan. Semakin banyak teman semakin memudahkan orang untuk menjalani hidup, dengan saling membantu. Memang manusia tidak bisa hidup sendiri tanpa bantuan orang lain, maka dari itu kehadiran teman yang memiliki kemampuan dan pengetahuan yang berbeda, sangat membantu satu sama lain.

Faktor keempat adalah pendidikan yang semakin tinggi. Pada zaman reformasi, sarjana - lulusan strata satu- sangat diagung-agungkan atas keilmuannya. Akan tetapi untuk saat ini, mahasiswa pascasarjana yang belajar pada strata dua hitungannya sudah jutaan. Tidak terbatas laki-laki dan perempuan, justru di kelas-kelas perkuliahan saat ini lebih banyak didominasi oleh kaum hawa. Ini menunjukkan bahwa perempuan sudah bukan bersikap pasif lagi seperti dulu.

Faktor kelima, penemuan-penemuan di bidang teknologi yang menjadikan akses keilmuan dan informasi semakin mudah didapat. Teknologi-teknologi canggih hari demi hari ditemukan dan dikembangkan, khususnya barang-barang elektronik seperti komputer, laptop, notebook, netbook, smartphone, ipad, dll. Barang-barang elektronik ini sangat memudahkan akses informasi didapat dengan dukungan koneksi internet. Apa saja yang diinginkan dengan mudah saja diakses. Hal ini menjadikan pengetahuan dan wawasan semakin luas dan mudah dikuasai.

Sehingga perubahan makna hak ijbar disebabkan karena beberapa hal. Pertama, tingkat kedewasaan setiap orang berbeda. Kedua, kondisi sosial masyarakat yang semakin maju. Ketiga, perkembangan pergaulan dan interaksi antar manusia semakin bebas. Keempat, pendidikan yang semakin tinggi. Kelima, penemuan-penemuan di bidang teknologi yang menjadikan akses keilmuan dan informasi semakin mudah didapat.

\section{Simpulan}

Mengacu pada pembahasan yang ada, konsep hak ijbar dalam catatan sejarah mengalami perubahan. Pada masa awal syariat Islam mayoritas para ulama mazhab mengakui adanya hak ijbar pada wali. Sehingga seorang ayah bisa memaksa anak perempuannya kawin, meskipun ada pendapat yang tidak mengiyakannya. Kemudian dengan munculnya Undang-Undang Perkawinan dan Kompilasi Hukum Islam di Indonesia, maka hak ijbar secara mutlak semestinya tidak bisa dipraktekkan lagi. Terlihat dalam beberapa

${ }^{29}$ Husein Muhammad, Figh Perempuan Refleksi Kyai Wacana Agama dan Jender, cet. ke- 2, (Yogyakarta: LKIS, 2002), hlm. 80. 
pasal yang menyatakan bahwa persetujuan dari kedua mempelai-calon suami dan calon istri-menjadi bagian yang tak terpisahkan dari perkawinan itu sendiri.

Perubahan makna hak ijbar terjadi pada keluarga pesantren di Pamekasan. Pada keluarga pesantren di Pamekasan, mayoritas memahami konsep hak ijbar yang berbeda. Tidak bisa disamakan konsep hak ijbar pada zaman dahulu dengan zaman sekarang. Pada zaman dahulu hak ijbar memang dirasa sesuai dengan kondisi masyarakatnya. Tetapi pada masa sekarang sudah tidak relevan lagi. Hak ijbar semestinya bisa dimaknai berbeda. Hal ini disebabkan beberapa hal, Pertama, tingkat kedewasaan setiap orang berbeda. Kedua, kondisi sosial masyarakat yang semakin maju. Ketiga, perkembangan pergaulan dan interaksi antar manusia semakin bebas. Keempat, pendidikan yang semakin tinggi. Kelima, penemuan-penemuan di bidang teknologi yang menjadikan akses keilmuan dan informasi semakin mudah didapat.

\section{DAFTAR PUSTAKA}

Abu al-Walid Muhammad bin Ahmad bin Rusyd al-Qurthubi al-Andalusi, Bidâyat alMujtahid wa Nihâyat al-Muqtasid,Vol. II, Beirut: Dar al-Fikr,t.t.

Akh. Minhaji, Sejarah Sosial dalam Studi Islam, Yogyakarta: Sunan Kalijaga Press, 2013. Al-Maraghi, Tafsîr Al-Marâghi, Jilid 17, Alih Bahasa Bahrun Abu Bakar, Cet Kedua, Semarang: Toha Putra, 1993.

Elizabeth B. Hurlock, Developmental Psychology A Life Span Approach, New York: Mc. Graw Hil Book, 1980.

Hamka, Tafsîr al-Azhâr, Juz 21, 22, 23 dan 24, Jakarta: Yayasan Nurul Islam, 1984.

Ibnu 'Abdi al-Baqi bin Yusuf al-Zarqani, Sharh Muwatta' al-Imam Malik, Mesir: Maktabah wa Matba'ah Mustafa al-Babi al-Halabi wa Awladih, 1962.

Imam Malik, al-Muwatta', Bab Nikah, Hadits No. 967.

Jalaluddin al-Mahalli, Jalaluddin as-Suyuthi, Kitab Tafsir Jalalain.

Kamal al-Din Muhammad al-Siwasi, Syarh Fath al-Qadir, Vol. III, Beirut: Dar al-Fikr,t.t. Khoiruddin, Nasution, Hukum Perkawinan 1, Yogyakarta: ACAdeMIA + TAZZAFA, 2005. Kompilasi Hukum Islam, Inpres No. 1 Tahun 1974.

Muhammad Husein, Fiqh Perempuan Refleksi Kyai Wacana Agama dan Jender, cet. ke- 2, Yogyakarta: LKIS, 2002.

Quraish Shihab, Muhammad, Tafsir Al-Misbâh, Jilid II, Bandung: Lintera Hati, 2004.

Sahnun, al-Mudawwanah, Jilid III.

Shams al-Din al-Sarakhsi, al-Mabsut, V, Beirut: Dar al-Ma'rufah, 1989. 
50 | Asy-Syari'ah Vol. 22 No.1, Juni 2020

S. Wojowasito, Kamus Umum Belanda Indonesia, Jakarta: PT. Ikhtiar Baru Van Hoves, 1990.

Undang-Undang No. 1 Tahun 1974 tentang Perkawinan.

Undang-Undang No. 23 tahun 2002 tentang Perlindungan Anak.

Yusuf al-Qardhawi, http://anawaladunsholih.blogspot.com/2011/11/kesalahan-dalammemahami-konsep-ijbar.html. 
Asy-Syari'ah (P-ISSN: 2086-9029 E-ISSN: 2654-5675) is a periodical scientific journal that publishes various results of studies and research, literature review, and other scientific works whose scope covers the field of Islamic law/sharia, law and society in monodisciplinary, interdisciplinary, and multidisciplinary manners. The journal aims to expand and create innovative concepts, theories, paradigms, perspectives and methodologies in the above said scope. The Journal is published twice a year (june and december) by Faculty of Shariah and Law, Sunan Gunung Djati State Islamic University Bandung in collaboration with Asosiasi Sarjana Syariah Indonesia (ASSYI).

\section{EDITORIAL OFFICE:}

Fakultas Syariah dan Hukum UIN Sunan Gunung Djati Bandung J1. Raya A.H. Nasution No. 105 Cibiru Kota Bandung, 40614

Tlp/Fax: +022-7802278 Faks. 022-7802278

Website http://journal.uinsgd.ac.id/index.php/asy-syariah/index

E-mail: Jurnalasy-syariah@uinsgd.ac.id 